\title{
Hysteresis Effect on Unemployment for Men and Women: A Panel Unit Root Test for OECD Countries
}

\author{
Selahattin Bekmez ${ }^{1} \&$ Aslı Özpolat ${ }^{2}$ \\ ${ }^{1}$ Dept. of Economics, Faculty of Economics and Administrative Sciences, Gaziantep University, Turkey \\ ${ }^{2}$ Oguzeli Vocational School, Gaziantep University, Turkey \\ Correspondence: Asst. Prof. Dr. Aslı Özpolat, Oguzeli Vocational School, Gaziantep University, Turkey.
}

Received: February 17, 2016

Accepted: March 9, 2016

Online Published: March 21, 2016

doi:10.5430/ijfr.v7n2p122

URL: http://dx.doi.org/10.5430/ijfr.v7n2p122

A priliminary version of this paper has been presented in the $18^{\text {th }}$ Eurasia Business and Economics Conference, Sharjah, UAE in January 8-10, 2016.

\begin{abstract}
There are two major hypotheses about the dynamics of unemployment in the literature: (i) natural rate of employment hypothesis, (ii) unemployment hysteresis hypothesis. The natural rate of employment hypothesis (NAIRU) implies a stable relationship between unemployment and business cycles in the long run. This means economic shocks arising in the business cycle creates a temporary imbalance in the unemployment rate. In other words, after an economic shock, the unemployment rate will return to long-term equilibrium level. In contrary to this argument, according to unemployment hysteresis hypothesis, unemployment move away from equilibrium state due to economic shocks and this state continues in the long run. The persistent imbalance means that unemployment have mean-deviation in the long run. As econometric approach, the unemployment series have an unstable trend. If unemployment rate is stable in the long run, the hysteresis effect becomes not valid. That is why the relationship between unemployment rate and business cycle will be the main issue of this study. According to that the hysteresis effect on unemployment rate in OECD countries has been analyzed. In this research the hysteresis effect on unemployment for women and men has also been separately examined. Thus, the research would allow us to distinguish and compare the gender differentiation within the OECD countries. The models have been estimated using yearly unemployment rate data from 1991 to 2014 for OECD countries and obtained from ILO statistics. Within the mentioned context above, Hysteresis effect has been analyzed with Panel Unit Root Tests, which both allowing and not allowing structural breaks. It is expected that the hysteresis effect on unemployment differs in terms of both gender and country level.
\end{abstract}

Keywords: hysteresis effect, unemployment, gender differentiation, Panel Unit Root Test

\section{Introduction}

There are two main theories explaining the relationship between unemployment and cyclical fluctuations. The first of one is the natural rate of unemployment or NAIRU expresses that unemployment rate is the mean reverting process. The second one is the "hysterisis" hypothesis expresses that economic shocks leave a lasting impact on the unemployment rate (Camarero and Tamarit, 2004:413).

There are many studies about effect of the presence of hysteresis hypothesis or NAIRU on the unemployment rate in economic literature. Most of the studies mentioned analyzed the presence of the hysteresis effect with classical unit root tests for countries or groups of countries. Recently, the models in the studies are mainly use unit root tests with structural breaks. The main difference between these tests is the reduction in the reliability of the result, if the impact of structural breaks is ignored. In addition to this, the labor market in these studies is mainly taken as a whole. The studies that make labor market distinctions such as sector, gender, age group and education are in the minority.

The importance of this study is to investigate unemployment hysteresis according to gender differentations. When different labour market dynamics for men and women are considered, the necessity of such a study becomes an important issu to investigate. Within this context, the hysteresis of unemployment in OECD countries will be examined on the basis of gender differentiation. 
The study consists of five parts. General theory and literature about unemployment hysteresis will be given in the first section. Issues regarding the gender differences in the labor market will be discussed in the second section. A general description of unit root tests to be used in this study will be given in the third section. The fourth section of the paper has been planned as two phases. In the first stage, classical panel unit root tests (IPS, LLC MW) without structural breaks will be contructed for unemployment series. In the second stage, The Panel LM unit root test with structural breaks will be analyzed. The last section includes the results.

\section{General Theory of Hysteresis on Unemployment}

Natural Unemployment Rate is determined by at the point where inflation remains constant according to macroeconomic theory. The principle underlying the Phillips Curve, it is assumed that there is a trade-off between unemployment and inflation. This theory implies that when the actual rate of inflation and the expected rate of inflation are equal, the unemployment rate indicates that the "natural" or "equilibrium" state. Natural unemployment rate hypothesis implies that because of the trade-off between inflation and unemployment, the shocks occurring in the economy refers to the leave a temporary impact on unemployment (Phelps, 1967:256). Hereunder, demand and/or supply fluctuations constitute deviations from the natural balance of the unemployment rate. These deviations cause the unemployment rate returns to normal level by triggering a change in inflation (Song and Wu, 1998:181).

"Histeresis" hypothesis is described under three different approaches, the "Physical Capital", "Human Capital" and "Insider-outsider". According to Physical Capital Approach, the adverse shocks in the economy leads to a decrease in demand for labor, and this process creates a long-term unemployment. Human Capital Approach, in general, shows that workers will lose their desire and ability in unemployment period and this situation represent to reduce the labor supply in the long run (Blanchard and Summers, 1986:26). The Insider-Outsider Approach forms by Blanchard and Summers (1986) is the basis of the unemployment Histeresis Hypothesis. According to this approach, the existence of asymmetry between insiders (the unemployed) and outsiders (those who are employed) during wage bargaining is basic point in Histeresis occurrence. When the wage rate negotiations started between companies and insiders, the outsiders has no effect on the process. Thus, shocks occurring in the economy lead to a reduction in employment and the equilibrium wage change. For the theory, the impact of economic shocks on the unemployment rate is permanent in the long term. So, unemployment series represent a non-stationary process.

Phillips curve with hysteresis function has been described as follows (Song and $\mathrm{Wu}, 1998: 182-183$ ):

$$
P_{t}=E_{t-1} P_{t}-\beta\left(U_{t}-U_{t}^{*}\right),
$$

$P_{t}=$ The current inflation rate

$E_{t-1} P_{t}=$ The expected inflation rate

$U_{t}=$ The current unemployment rate

$U_{t}^{*}=$ The natural unemployment rate

$\beta=$ Constant

According to Hysteresis Hypothesis, the natural rate of unemployment is function of the past actual unemployment rate. The model is as follows:

$$
U_{t}^{*}=U_{t-1}^{*}+\theta\left(U_{t-1}-U_{t-1}^{*}\right)
$$

In the model, $\theta$ is a fixed parameter and if it is non-zero $(\theta \neq 0)$, this parameter indicates the presence of hysteresis effects. In other words, if it is equal to zero $(\theta=0)$, the natural rate does not change over time and the natural rate hypothesis is valid.

These theories are formulated with the degree of integration of the unemployment rate in the econometric time-series models. Thus, when the level stationary supports that natural unemployment hypothesis situation, the unit root process implies the existence of hysteresis effects (Camarero and Tamarit, 2004:413).

Unemployment Histeresis has been tested with unit root models covering many countries and groups of countries in the literature. Applied unit root tests can be categorized in two groups. Classical unit root tests (ADF etc.) are in the first group, the panel unit root tests is the second group. The results obtained with classical unit root tests do not provide satisfactory results. The panel unit root tests give more accurate results because of the cross-sectional dimension and increasing the amount of information for each time period (Camarero and Tamarit, 2004:414). Road (1996) applied the ADF unit root test for the 16 OECD countries in his work and he found that Histeresis has a strong impact on unemployment in all countries with the exception of one country. In contrast, Song and Wu (1998), applied the ADF, PP and Panel Unit Root Test for the 15 OECD countries and reached the conclusion of hypothesis of natural unemployment is valid. Arestis and Mariscal (2000) implemented Perron unit root analysis allowing 
structural breaks in the 22 OECD countries. According to that, they reached that the series have unit root for 10 countries, level stationary process for 9 countries and the trend stationary for 3 countries. Camarero and Tamarit (2004), made the ADF unit root analysis for 19 OECD countries and found that the hysteresis effect is valid only in 7 countries. Lee and Chang (2008) applied LM Unit Root test for 14 OECD countries and they strongly refused the impact of Histeresis. The empirical findings of international studies in the literature vary. This case may be result from the preferred unit root tests and differences in the time andcross-section dimension.

Ledesma (2002) implemented IPS unit root test in his study using quarterly series between the years of 1985-1999 for $12 \mathrm{EU}$ countries and found the presence of hysteresis effects in the analysis. Katsumi (2000) used in the MLR model for Greece and has indicated that shocks occurring on the economy have lasting effects on unemployment. Chang Lee and Nieh\& Wei (2005) used the SURADF panel unit root test for 10 EU countries and they found the existence of Histeresis effects except two countries. Gustavson (2006), made ADF and CSR unit root tests for Australia, Canada, Finland, Sweden and USA and reached the conclusion that the hypothesis of natural unemployment in current countries except Australia. Gomes and Silva (2008), applied LM Unit Root Test and have concluded the presence of Histeresis effect in the unemployment for Brazil and Chile. Arı, Zeren and Özcan (2013) made PANKPSS unit root test allowing 5 breaks for East Asia and the Pacific and concluded that these countries have no Histeresis effect. With the models using unemployment rates, also models analyzed the relationship between unemployment rate, wages, labor productivity are in the literature. Accordingly, Iregua and Otero (2003) tested the effect of the presence of Histeresis for Colombia. Asymmetric Error Correction model was applied in this study and the average wage, consumer price index, labor productivity and rate of unemployment series were used in the model. Accordingly, wages situated upper on the balance of long-term increases unemployment, but wages under the balance reduce unemployment. The findings represent the Histeresis effect.

As far as our best knowledge, there are only three studies analyzing the hysteresis effect on unemployment according to the gender differences in the economic literature. Queneau and You (2011) applied ADF Unit Root test for 8 countries and found gender differences for the three countries in their study. Tolvi (2003) used the LM the NLS estimate for Finland and found unemployment is more permanent for women and youth, Koustas and Veloce (1996) found unemployment is less permanent for women and young people. In their study they used ARFIMA analysis for Canada.

\section{Gender Differentiation in Labour Market}

When general labor market evaluated in the context of gender equality, it has different characteristics for men and women. Therefore, the effect of Histeresis or NAIRU on unemployment may vary for men and women. In the labor market, there are differences in recruitment process, payment, promotion, and trade union activities between men and women. However, reducing labor costs are among the fundamental causes of gender discrimination depending on the culturel, social and economic characteristics of the countries (Akpınar, 2005:3-5).

Queneau and You (2011) have mentioned four factors that make gender differences in the unemployment rate in OECD countries. One of them, gender differences in labor force's attachment. Other factors are gender differences in "job search way; the distribution of employment by gender across industries and institutional factors such as the insurance system, the provision of compulsory family benefits or the extent of gender discrimination in the labor markets". Unemployment data for men and women are shown in Figure 1 for certain countries:

Australia

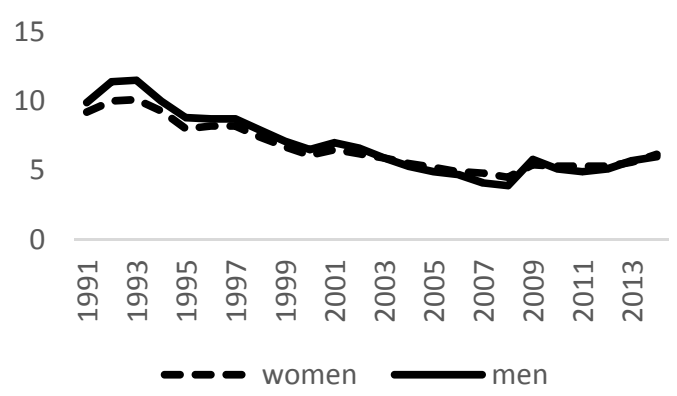

Austria

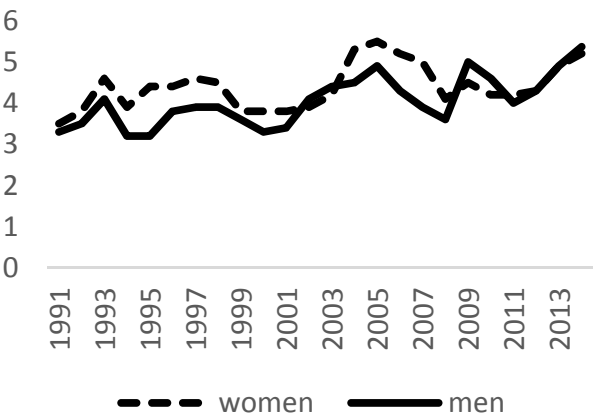


Belgium

15

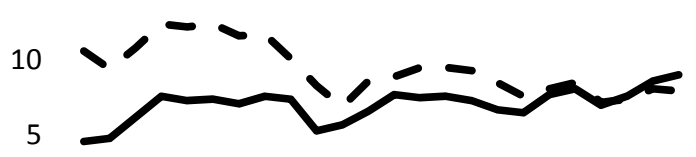

0

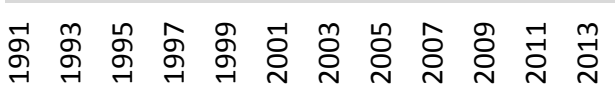

- women men

Czech Republic
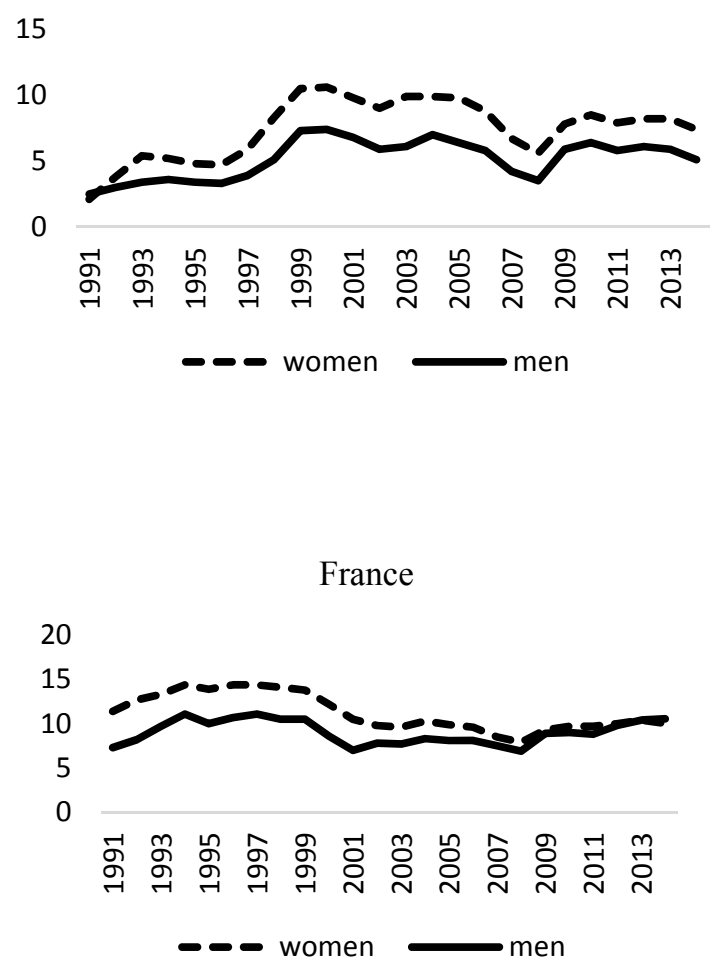

Greece

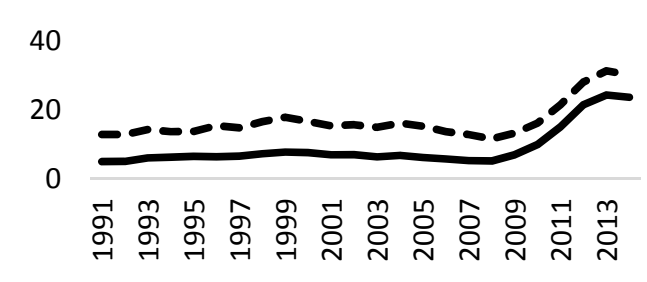

- w women men
Canada

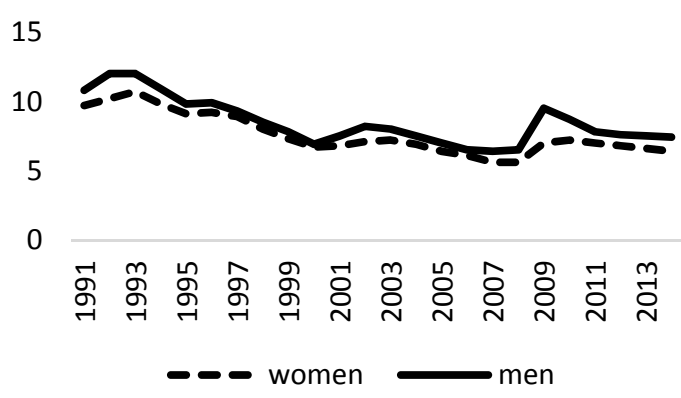

Denmark

15

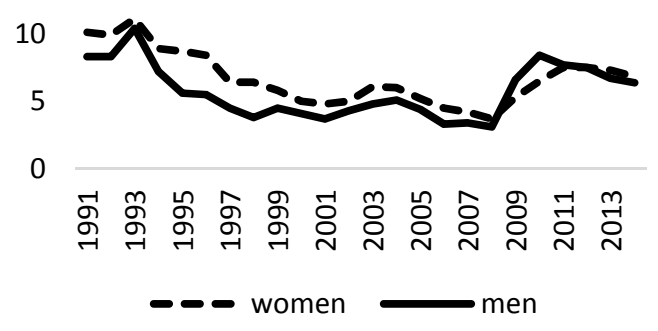

Germany

15

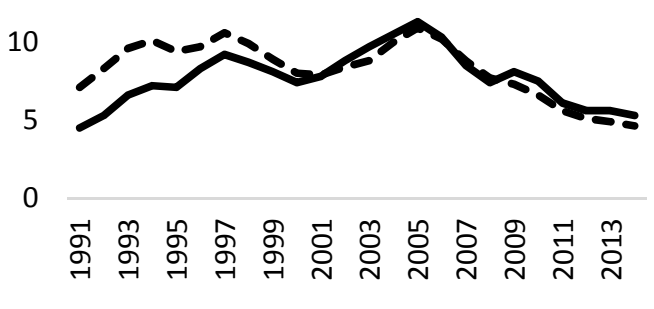

- - women men

Italy

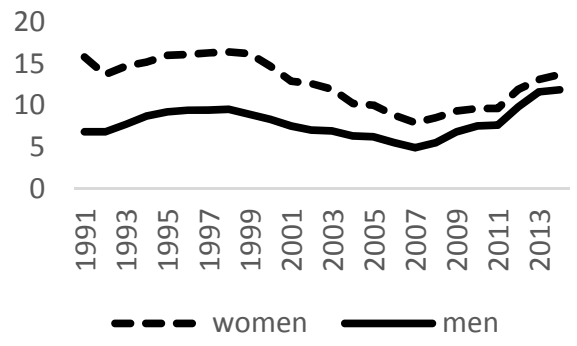


Nerherlands

15

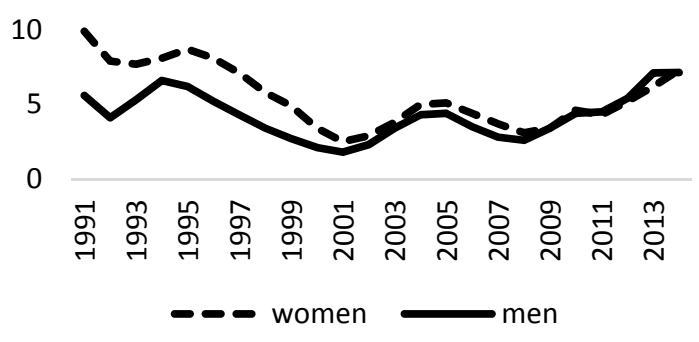

Norway

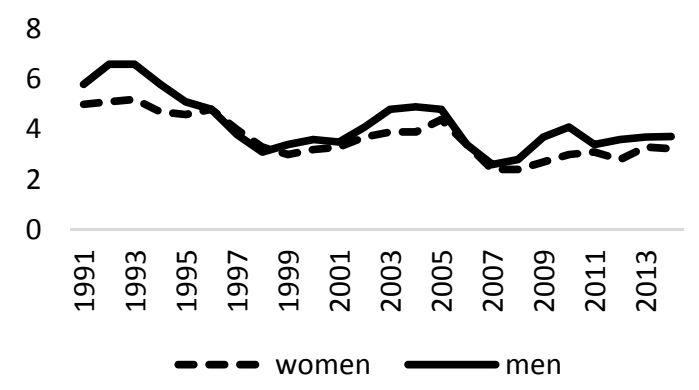

Portugal

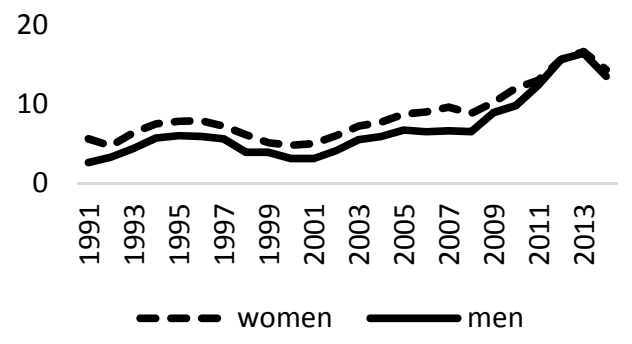

New Zealand

15
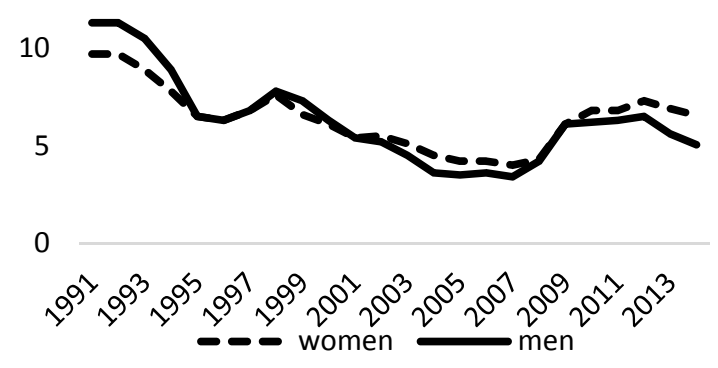

Poland

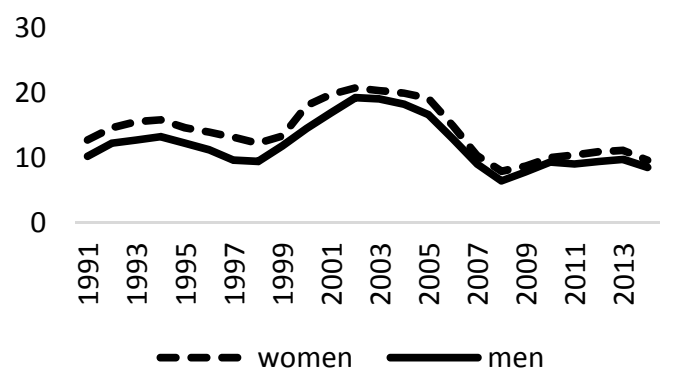

Spain

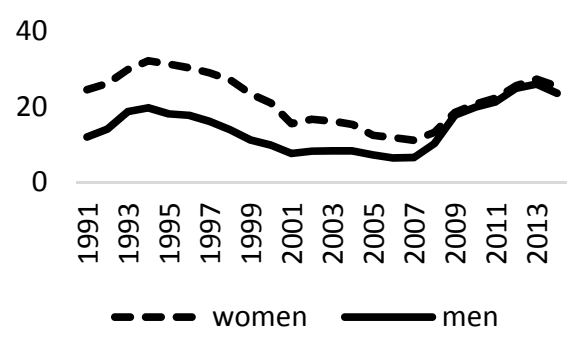

Turkey

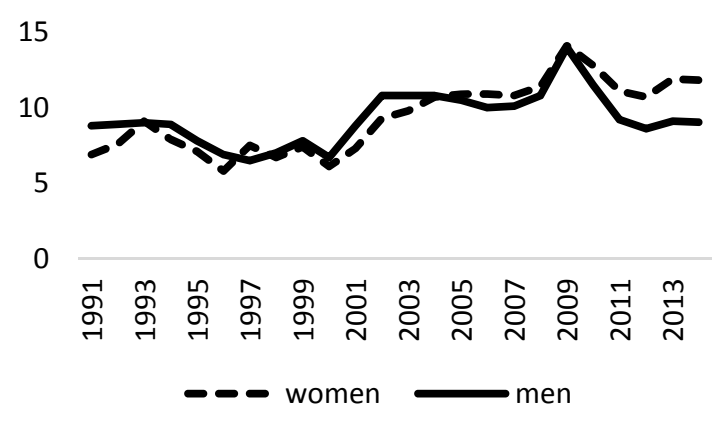

Figure 1. Men and Women Unemployment Rate for Each Country (OECD: 2015) 
We see from the Figure 1 that there is a presence of gender differentiation in all countries, expect Australia. While the case of gender differentaions militate in favor of women in Canada, Germany and Norway, it is in favor of men in remaining countries. Thus, we expect that our findings also will indicate that Histeresis effect will vary for men and women in the most of the OECD countries.

\section{Model}

Unemployment Histeresis assumes that the unemployment series is non- stationary series. In this context, the unit root tests are used to measure the presence of Histeresis. In the first stage of the study, IPS, LLC and Maddala-Wu tests that ignore the structural breaks will be implemented. The second stage of the study Panel LM unit root tests analyzing the stability of series under the structural break assumption will be implemented.

\subsection{Im, Pesaran and Shin Unit Root Test (IPS)}

IPS unit root test, was developed by Im, Pesaran and Shin (2003). Basically IPS unit root test is obtained by taking the average ADF unit root test calculated for all units in the panel. Testing hypothesis are as follows:

$$
\begin{aligned}
H_{0}: \beta_{i} & =0 \text { for all } \mathrm{i}, \\
H_{1}: \beta_{i}\left\langle 0, i=1,2, \ldots, N_{1}, \beta_{i}\right. & =0, i=N_{1}+1, N_{1}+2, \ldots . N
\end{aligned}
$$

The formulation of alternative hypothesis refers to change in $\beta_{i}$ for all unit in panel. Accordingly, each group unit

root test is not zero, i.e., $\lim _{N \rightarrow \infty}\left(N_{1} / N\right)=\delta, 0\langle\delta \leq 1$. Therefore, IPS t-test statistic expressed as average of ADF test for each unit (Baltagi, 2005:242):

$$
\bar{t}=\frac{1}{N} \sum_{i=1}^{N} t_{\rho i}
$$

Where $t_{\rho i}$ state $\mathrm{t}$ statistic of unit. Standardized $t$ statistics are the following:

$$
t_{I P S}=\frac{\sqrt{N}\left(t-\frac{1}{N} \sum_{i=1}^{N} E\left[t_{i T} \mid \rho_{i}=0\right]\right.}{\sqrt{\frac{1}{N} \sum_{i=1}^{N} \operatorname{var}\left[t_{i T} \mid \rho_{i}=0\right]}} \Rightarrow N(0,1)
$$

\subsection{Levin, Lin and Chu Unit Root Test (LLC)}

Levin, Lin and Chu (LLC) (2002) assume that there are $i=1, \ldots \ldots ., N$ groups and each unit contains $t=1, \ldots \ldots ., T$ observation. In this case, each time series may contain constant and time trend. Accordingly, it assumes that all series in the panel have first degree of patial auto-correlation, however all parameters in error process vary among units. In LLC unit root test, null hypothesis express that time series includes a unit root for each unit and alternative hypothesis state that these series are stationary (Baltagi, 2005:240).

$$
\begin{aligned}
& H_{0}: \rho_{i}=\rho=1 \\
& H_{1}: \rho_{i}=\rho\langle 1
\end{aligned}
$$

Hypothesis point out as three model (Levin vd., 2002:5-6).

$$
\begin{gathered}
\text { Model1: } \Delta y_{i t}=\delta y_{i t-1}+\zeta_{i t} \\
\text { Model 2: } \Delta y_{i t}=\alpha_{0 i}+\delta y_{i t-1}+\zeta_{i t} \\
\text { Model 3: } \Delta y_{i t}=\alpha_{0 i}+\alpha_{1 i t}+\delta y_{i t-1}+\zeta_{i t}-2\langle\delta \leq 0 i=1, \ldots, N
\end{gathered}
$$

In model 1 , panel unit root test is evaluated the null hypothesis $H_{0}: \delta=0$ and the alternative hypothesis $H_{1}: \delta\langle 0$. In model 2 'de series $\left\{y_{i t}\right\}$ have individual specific mean however does not include a time trend. At this stage, the 
panel unit root test evaluate the null hypothesis $H_{0}: \delta=0$ and $\alpha_{0 i}=0$, alternative hypothesis $H_{1}: \delta\langle 0$ and $\alpha_{0 i} \in R$. In model 3 series have individual specific mean and time trend. So, null hypothesis and alternative hypothesis are as follows respectively: $H_{0}: \delta=0 \alpha_{1 i}=0, H_{1}: \delta\left\langle 0 \alpha_{1 i} \in R\right.$

Maintain hypothesis of LLC Panel unit root test is

$$
\Delta y_{i t}=\delta y_{i t-1}+\sum_{L=1}^{P_{i}} \theta_{i L} \Delta y_{i t-L}+\alpha_{m i} d_{m t}+e_{i t}, m=1,2,3 .
$$

In the implementation of LCC panel unit root test, one model consisting of three steps is suggested. In step 1, ADF regressions analyzed for each individual in the panel, in step 2, long run and short run standart deviation are assumed, and in the last step, the pooled t-statistics are computed.

\subsection{Maddala-Wu Unit Root Test}

Maddala and $\mathrm{Wu}$ (1999) Unit Test is based on the use of the Fisher Test. The null and alternative hypotheses are in the following.

$$
\begin{gathered}
H_{0}: \beta_{i}=0 \\
H_{1}: \beta_{i}<0
\end{gathered}
$$

For the Fisher test, the ADF (p) test for each individual series is applied. The following two models are estimated (Maddala and $\mathrm{Wu} ; 1999: 9$ ).

$$
\text { Drift model: } \Delta y_{i, t}=\alpha_{i}+\rho_{i} y_{i, t-1}+\sum_{j=1}^{\rho} \gamma_{i j} \Delta y_{i, t-j}+\text { residual }
$$

$$
\text { Trend model: } \Delta y_{i, t}=\alpha_{i}+\delta_{i} t+\rho_{i} y_{i, t-1}+\sum_{j=1}^{\rho} \gamma_{i j} \Delta y_{i, t-j}+\text { residual }
$$

Where $p=0,1,2$ are used and $p$-values using the Dickey-Fuller t-distributions generated by 100,000 simulations for the corresponding ADF t-test statistics are computed.

\subsection{Panel LM Unit Root Test}

Unit root tests allowing structural breaks are applied generally in the recent literature. Especially, it is important to implement these tests for the series with high sensitivity against economic shocks. The main difference between unit root tests allowing structural breaks and the unit root tests ignoring structural breaks is that series can be found non-stationary although they are stationary under structural breaks. In order to solve this problem, Panel LM unit root test has been developed by Lee and Strazicich (2004).

In the model, data generating process (DGP) has formulated as follows (Lee and Strazicich, 2004:3):

$$
y_{t}=\delta Z_{t}+X_{t}, X_{t}=\beta X_{t-1}+\varepsilon_{t},
$$

$Z_{t}$ contains exogeneous variables in the equation. The null hypothesis describe as $\beta=1$. If $Z_{t}=[1, t]$, DGP is the no break LM Unit Root of Schmidt ve Phillips (1992). Lee veStrazicich (2004) consider two models as Model A and Model $\mathrm{C}$ of structural changes.

"Model A" indicates that "crash model" and under the alternative hypothesis, it allows one -time change in intercept. "Model A" describes by $Z_{t}=\left[1, t, D_{t}\right], t \geq T_{B}+1$ for $D_{t}=1$ ve $t \leq T_{B}+1$ for $D_{t}=0$ and $T_{B}$ is the time period of structural break.Under the alternative hypothesis, "Model C" contains for a shift in intercept and change in trend slope. Accordingly, $Z_{t}=\left[1, t, D_{t}, D T_{t}\right]^{\prime}$ describe as Model C. Where $t \geq T_{B}+1$ for $D T_{t}=t-T_{B}$

According to LM principle, unit root test is obtained from regression as following:

$$
\Delta y_{t}=\delta^{\prime} \Delta Z_{t}+\phi \tilde{S}_{t-1}+u_{t}
$$


Where $\tilde{\delta}_{t}=y_{t}-\tilde{\psi}_{x}-Z_{t} \tilde{\delta}, t=2, \ldots, T$, when $\tilde{\delta}$ state that coefficient in the reggessions of $\Delta y_{t}$ on $\Delta Z_{t}, \tilde{\psi}_{x}$ is obtain from $y_{t}-Z_{t} \tilde{\delta}$. So, LM Unit Root, $\tilde{\tau}=$ t statistics null hypothesis describe as $\Phi=0$. In the model, break time $\left(T_{B}\right)$ is the minimum point of $\tilde{\tau}$ test statistics. T-test statistics are as follows:

$$
\operatorname{lnf} \tilde{\tau}(\tilde{\lambda})=\operatorname{Inf}_{\lambda} \tilde{\tau}(\lambda), \lambda=T_{B} / T
$$

As t-statistics is less than critical values, the null hypothesis $\mathrm{H}_{0}$ is accepted. Critical values are obtained from the paper Lee and Strazicich (2004) for Model A and Model C with one break.

\section{Results}

In the study, we used classical panel unit root tests not taking the structural breaks into accunt and the Panel LM unit root testing the unit root process under the structural breaks for 17 OECD countries. The data set covers the unemployment rate by sex, age 15-64, between the years of 1991-2014. Data has been obtained from the International Labour Organisation (ILO) and World Bank.

Classical unit root test results are listed in Table 1 for men $\left(U_{\mathrm{m})}\right.$ and women $\left(\mathrm{U}_{\mathrm{w}}\right)$. Panel unit root tests are Levin-Lin-Chu (LLC), Im, Pesaran Shin (IPS) and Maddalena-W (MW) tests.

Table 1. Unit Root Test results

\begin{tabular}{lcccccc}
\hline \hline & \multicolumn{2}{c}{ LLC } & \multicolumn{2}{c}{ IPS } & MW \\
\hline Variable & Constant & Constant\&Trend & Constant & Constant\&Trend & Constant & Constant\&Trend \\
$U_{W}$ & -1.535 & 2.267 & -0.989 & 0.677 & 36.337 & 31.264 \\
& $(0.0624)$ & $(0.9883)$ & $(0.1611)$ & $(0.7511)$ & $(0.3603)$ & $(0.6024)$ \\
$U_{M}$ & -4.380 & 0.182 & -4.189 & -0.829 & 73.240 & 41.526 \\
& $(0.0000)$ & $(0.5725)$ & $(0.0000)$ & $(0.2035)$ & $(0.0001)$ & $(0.1755)$ \\
\hline \hline
\end{tabular}

Panel unit root tests include two models; one with only change in constant and the second with a change in both constant and trend. According to data obtained, $\mathrm{H}_{0}$ hypothesis are accepted for women in all tests. Therefore unemployment series contains a unit root for women. Accordingly, the effect of Histeresis on unemployment for women is also accepted. This means that any shock occurring in the economy leave long-term effects on women unemployment rate and leave it away from the equilibrium point. Test results for the males are level stationary under the "contant change" assumption, but the series contains a unit root process under the "trends and constant change" assumption. According the series contain trend that appeared in Figure 1, the existence of hysteresis effects for men is accepted. LM unit root test panels containing one structural breaks has been estimated as Model A and Model C.

Table 2 contains the results of Model A with one structural break for women. If the absolute value of the test statistic is greater than the critical value, the null hypothesis $\left(\mathrm{H}_{0}\right)$ is rejected. Because the null hypothesis states that the series have unit root. When the null hypothesis rejected, it means that the unemployment hysteresis effects is not valid. 
Table 2. Panel LM Unit Root Test result for women (Model A)

\begin{tabular}{llll}
\hline \hline Countries & t-ist. & LagValues & Breakpoint \\
\hline Australia & $-3.991^{* *}$ & 1 & 2001 \\
Austria & -2.372 & 0 & 2009 \\
Belgium & $-3.460^{*}$ & 1 & 2001 \\
Canada & -3.032 & 1 & 2010 \\
CzechRepublic & -1.113 & 1 & 2002 \\
Denmark & -1.657 & 0 & 2008 \\
France & -1.765 & 0 & 2001 \\
Germany & -2.006 & 1 & 1994 \\
Greece & -2.749 & 1 & 2002 \\
Italy & -2.183 & 1 & 2011 \\
Netherlands & -2.436 & 1 & 2009 \\
New Zealand & -2.968 & 1 & 1998 \\
Norway & -3.137 & 1 & 2004 \\
Poland & -2.449 & 1 & 2003 \\
Portugal & -2.736 & 1 & 2006 \\
Spain & -2.102 & 1 & 2000 \\
Turkey & -1.729 & 0 & 2000 \\
\hline \hline
\end{tabular}

Critical Values: $\% 1-4.239 ; \% 5,-3.566 ; \% 10,-3.211 ; *, * *$ and $* * *$ denote significance at the 10,5 and $1 \%$ levels, respectively

The series contains a unit root in all countries other than Australia and Belgium. Therefore, the presence of Histeresis effect on unemployment for women is recognized by the Model A in these countries. The Model C results are in the Table 3 for women. Model C is the LM unit root test which takes "changes is constant and trends" into account.

Table 3. Panel Unit Root Test result for women (Model C)

\begin{tabular}{|c|c|c|c|c|c|c|}
\hline Countries & t-ist. & \multicolumn{2}{|c|}{ LagValues } & \multicolumn{2}{|l|}{ Breakpoint } & $\begin{array}{l}\text { Location of } \\
\text { Break } \lambda\end{array}$ \\
\hline Australia & $-4.476^{*}$ & 1 & & 2002 & & 0.5 \\
\hline Austria & -3.075 & 0 & & 2008 & & 0.3 \\
\hline Belgium & -3.575 & 1 & & 2009 & & 0.2 \\
\hline Canada & $-5.086^{* *}$ & 1 & & 2007 & & 0.3 \\
\hline CzechRepublic & $-7.357 * * *$ & 1 & & 2001 & & 0.5 \\
\hline Denmark & -2.486 & 0 & & 2001 & & 0.5 \\
\hline France & -2.833 & 0 & & 2001 & & 0.5 \\
\hline Germany & -3.506 & 1 & & 2001 & & 0.5 \\
\hline Greece & -3.471 & 1 & & 2003 & & 0.5 \\
\hline Italy & -3.165 & 1 & & 2007 & & 0.3 \\
\hline Netherlands & $-5.177 * *$ & 1 & & 1998 & & 0.3 \\
\hline New Zealand & -3.958 & 1 & & 2008 & & 0.3 \\
\hline Norway & -3.122 & 1 & & 2004 & & 0.4 \\
\hline Poland & $-4.600 *$ & 1 & & 2003 & & 0.5 \\
\hline Portugal & $-4.816^{* *}$ & 1 & & 2000 & & 0.4 \\
\hline Spain & -3.004 & 1 & & 2000 & & 0.4 \\
\hline Turkey & -2.231 & 0 & & 2001 & & 0.5 \\
\hline $\begin{array}{l}\text { Location of Break, } \lambda \\
\text { Critical Values }\end{array}$ & 0.1 & 0.2 & 0.3 & 0.4 & 0.5 & \\
\hline$\% 1$ & -5.11 & -5.07 & -5.15 & -5.05 & -5.11 & \\
\hline$\% 5$ & -4.50 & -4.47 & -4.45 & -4.50 & -4.51 & \\
\hline$\% 10$ & -4.21 & -4.20 & -4.18 & -4.18 & -4.17 & \\
\hline
\end{tabular}

$*, * *$ and $* * *$ denote significance at the 10,5 and $1 \%$ levels, respectively 
According to the data, $\mathrm{H}_{0}$ hypothesis is rejected for 6 countries (Australia, Canada, Czech Republic, Netherlands, Poland, Portugal). These series are stationary for the specified countries. It refers that when the deviations occur due to long term fluctuations, the economy will return to equilibrium again. Thus it can be said that NAIRU hypothesis is true for those countries. Hysteresis effect of unemployment is valid for 11 countries including Austria, Belgium, Denmark, France, Germany, Greece, Italy, New Zealand, Norway, Spain and Turkey. When compared with Model A, trend stationary process is obtained for 5 countries (Canada, Czech Republic, Netherlands, Poland, Portugal). According to Lee and Chang (2008), this situation may imply that total demand policy has been over implemented. Because, in this case, there is no evidence to support the existence of unemployment Histeresis. Table 4 contains the results of Model A with one structural breaks for men.

Table 4. Panel Unit Root Test result for men (Model A)

\begin{tabular}{llll}
\hline \hline Countries & t-ist. & LagValues & Breakpoint \\
\hline Australia & $-4.401^{* * *}$ & 1 & 2001 \\
Austria & -2.547 & 1 & 2007 \\
Belgium & -2.609 & 1 & 2000 \\
Canada & -3.161 & 1 & 2010 \\
CzechRepublic & -2.138 & 1 & 2002 \\
Denmark & -1.693 & 0 & 2009 \\
France & -2.190 & 1 & 2002 \\
Germany & -2.240 & 1 & 1996 \\
Greece & -2.371 & 1 & 2004 \\
Italy & -1.843 & 1 & 2008 \\
Netherlands & -2.409 & 1 & 2009 \\
New Zealand & -3.199 & 1 & 2005 \\
Norway & -2.991 & 1 & 1999 \\
Poland & -2.413 & 1 & 2003 \\
Portugal & $-3.739^{* *}$ & 1 & 1997 \\
Spain & -2.273 & 1 & 2008 \\
Turkey & -2.205 & 1 & 2000 \\
\hline \hline
\end{tabular}

Critical Values: \%1 -4.239; \%5, -3.566; \%10, -3.211; *,** and *** denote significance at the 10,5 and $1 \%$ levels, respectively

According to the obtained results, when considered the presence of the structural breaks, series include a unit root process in all countries except Portugal and Australia. Thus, the presence of unemployment hysterisisis is acceptable for men in these countries. Table 5 contains the results of Model $\mathrm{C}$ with one structural breaks for men.

When evaluating the findings in Table $5 ; \mathrm{H}_{0}$ hypothesis is accepted for the countries other than Poland, Australia, Canada, Czech Republic, Germany, Greece, Netherlands and New Zealand. Therefore, unemployment series do not include unit root with structural break in the specified countries. For both Model A and Model C, because of trend process of series, it can be said that there is the presence of hysterisis effect on unemployment rate in Austria, Belgium, Denmark, France, Italy, Norway, Portugal, Spain and Turkey. 
Table 5. Panel Unit Root Test result for men (Model C)

\begin{tabular}{|c|c|c|c|c|c|c|}
\hline Countries & t-ist. & LagValue & & Breakpoint & & $\begin{array}{l}\text { Location of } \\
\text { Break } \lambda\end{array}$ \\
\hline Australia & $-5.169 * * *$ & 1 & & 2001 & & 0.5 \\
\hline Austria & -3.441 & 1 & & 2006 & & 0.3 \\
\hline Belgium & -4.005 & 1 & & 2009 & & 0.2 \\
\hline Canada & $-5.359 * * *$ & 1 & & 2008 & & 0.3 \\
\hline CzechRepublic & $-5.256^{* * *}$ & 1 & & 1998 & & 0.3 \\
\hline Denmark & -2.847 & 1 & & 2007 & & 0.3 \\
\hline France & -2.759 & 1 & & 2002 & & 0.5 \\
\hline Germany & $-4.044 *$ & 1 & & 2001 & & 0.5 \\
\hline Greece & $-4.552 * *$ & 1 & & 2001 & & 0.5 \\
\hline Italy & -2.817 & 1 & & 2001 & & 0.5 \\
\hline Netherlands & $-5.884 * * *$ & 1 & & 1998 & & 0.3 \\
\hline New Zealand & $-4.627 * *$ & 1 & & 2007 & & 0.3 \\
\hline Norway & -3.566 & 1 & & 2001 & & 0.5 \\
\hline Poland & $-4.603^{*}$ & 1 & & 2003 & & 0.5 \\
\hline Portugal & -3.371 & 1 & & 1999 & & 0.4 \\
\hline Spain & -3.120 & 1 & & 2000 & & 0.4 \\
\hline Turkey & -3.718 & 1 & & 2000 & & 0.4 \\
\hline $\begin{array}{l}\text { Location of Break, } \lambda \\
\text { Critical Values }\end{array}$ & 0.1 & 0.2 & 0.3 & 0.4 & 0.5 & \\
\hline$\% 1$ & -5.11 & -5.07 & -5.15 & -5.05 & -5.11 & \\
\hline$\% 5$ & -4.50 & -4.47 & -4.45 & -4.50 & -4.51 & \\
\hline$\% 10$ & -4.21 & -4.20 & -4.18 & -4.18 & -4.17 & \\
\hline
\end{tabular}

$*$, ** and $* * *$ denote significance at the 10,5 and $1 \%$ levels, respectively

The unit root tests used in this study contain Model A, which include change in "constant" as well as Model C, which includes change in "constant and trend" in structural changes. The test statistics analyzed for Model A is less than absolute critical values (5\% significance level); the test statistics calculated for Model C is greater than absolute value of the critical value. Therefore, the results showed that while unemployment series have unit root with structural break, the series are stationary with structural breaks for Model C (Y1lanc1, 2009:332). When unemployment series are examined, it can be seen that there are breaks in "trend and constant". Therefore, under the scope of the study, results obtained in Model C can be more generalized.

\section{Conclusion}

The aim of this study is to examine the hysteresis effect on unemployment rate for women and men with unit root analysis in OECD countries. Basically, the presence of gender gap is not investigated, but difference between labor structure for women and men is reflected to analysis. In this context, first of all classical panel unit root tests without structural breaks (IPS, LLC MW) have been implemented. According to the results obtained, we see that histerisis effect on unemployment rate for women and men is not valid. Secondly, Panel LM Unit Root test which includes the structural break has been implemented. According to the results obtained in the analysis, there is no unemployment hysterisis for both groups in Australia, Canada, Czech Republic, Netherland and Poland.

The presences of hysteresis effect on umployment rate for both men and women is valid in Austria, Belgium, Denmark, France, Italy, Norway, Spain and Turkey. These findings indicate that in the countries where hysteresis effect on unemployment is valid, shocks in the economy and implemented stabilization policies create permanent changes in natural rate of unemployment. Also unemployment moves with non-stationary structure around a fluctuating median during the time period. In order to eliminate histersis effect on unemployment, it is essential that the policies increasing the aggregate demand must be implemented. If hysterisis effect is valid for only men or for only women, it can be said that there is heterogeneity on gender based employment structure among the countries. In this case, gender based labor market policies need to be implemented more carefully. However, when the hysteresis effect on unemployment present in both men and women, it does not mean that a gender gap is absent. Similarly, the absence of hysteresis effect does not give as an appropriate reason to make a comment regarding the gender gap.

\section{References}

Akpınar, T. (2005). AB İşgücü Piyasasında Cinsiyet Ayrımcılığının Boyutları ve Ortadan Kaldırmaya Yönelik Çalışmalar. Ankara Üniversitesi SBF Dergisi, 60(4). 
Arestis, P., \& veBiefang-FrisanchoMariscal, I. (2000). OECDUnemployment: Structural Breaks and Stationarity. Applied Economics, 32(4), 399-403. http://dx.doi.org/10.1080/000368400322570

Arı, A., Zeren, F., \& Özcan, B. (2013). DoğuAsyavePasifikÜlkelerindeİşsizlikHisterisi: Panel VeriYaklaşımı. Marmara Üniversitesi İ.I.B, 35(2), 105-122.

Baltagi, B. (2005). Econometric Analysis of Panel Data ( $3^{\text {rd }}$ ed.). John Wiley and Sons.

Bekmez, S. and Ozpolat, A. (2016). Hysteresis Effect on Unemployment in OECD Countries $18^{\text {th }}$ EBES Conference, Sharjah, UAE, January 8-10, 2016

Blanchard, O. J., \& Summers, L. (1986). Hysteresis and the Europeanunemployment problem. In S. Fischer (Ed.), NBER Macroeconomics Annual. Cambridge, MIT Press

Camarero, M., \& Tamarit, C. (2004). Hysteresis vs. Natural Rate of Unemployment New Evidence for OECD Countries. Economics Letters, 84(2004), 413-417. http://dx.doi.org/10.1016/j.econlet.2004.02.014

Chang, T., Lee, K. C., Nieh, C. C., \& Wei, C. C. (2005). An empirical note on testing hysteresis inunemployment for ten European countries: panelSURADF approach. Applied Economics Letters, 12, 881-886. http://dx.doi.org/10.1080/13504850500365871

Gomes, F., \& Silva, C. (2008). Hysteresis vs. natural rate of unemployment inBrazil and Chile. Applied Economics Letters, 15, 53-56. http://dx.doi.org/10.1080/13504850600675450

Gustavsson, M., \& Österholm, P. (2006). Hysteresis and Non-linearities inUnemployment Rates. Applied Economics Letters, 13(9), 545-548. http://dx.doi.org/10.1080/13504850500401437

Im, K., Pesaran, M. H., \& Shin, Y. (2003). Testing for Unit Roots in Heterogenous Panels. Journal of Econometrics, 115(1), 53-74. http://dx.doi.org/10.1016/S0304-4076(03)00092-7

Iregui, A., \& Otero, J. (2003). On the Dynamics of Unemployment in a Developing Economy: Colombia. Applied Economic Letters, 10, 895-898. http://dx.doi.org/10.1080/1350485032000162811

Katsimi, M. (2000). Stochastic Shifts in the Natural Rate of Unemployment: Evidence from Greece. Applied Economics Letters, 7(4), 239-242. http://dx.doi.org/10.1080/135048500351582

Koustas, Z., \& Veloce, W. (1996). Unemployment Hysteresis İnCanada: An Approach Based on Long-Memory Time Series Models. Applied Economics, 28, 823-31. http://dx.doi.org/10.1080/000368496328263

Ledesma, M. (2002). Unemployment Hysteresis in the US and the EU: A Panel Data Approach. Bulletin of Economic Research, 54(2), 0307-3378.

Lee, C. C., \& Chang, C. P. (2008). Unemployment Hysteresis in OECD Countries: Centurial Time Series Evidence with Structural Breaks. Economic Modelling, 25, 312-325. http://dx.doi.org/10.1016/j.econmod.2007.06.002

Lee, J., \& Strazıcich, M. C. (2004). Minimum LM Unit Root Test with OneStructural Break. Appalachian State University Working Papers, 4(17), 1-15.

Levin, A., Lin, C., \& Chu, J. (2002). Unit Roots Tests in Panel Data: Asymptotic and Finite Sample Properties. Journal of Econometrics, 108, 1-24. http://dx.doi.org/10.1016/S0304-4076(01)00098-7

Maddala, G. S., \& Wu, S. A. (1999). Comparative Study of Unit Root Tests with Panel Data and a New Simple Test. Oxford Bulletin of Economics and Statistics, 61, 631-652. http://dx.doi.org/10.1111/1468-0084.61.s1.13

Phelps, E. S. (1967). Phillips Curves, Expectations of Inflation and OptimalUnemployment Over Time. Economica, 34(3), 254-81. http://dx.doi.org/10.2307/2552025

Queneau, H., \& Sen, A. (2011). Evidence on the Dynamics of Unemployment by Gender. Applied Economics, 40(16), 2099-2108. http://dx.doi.org/10.1080/00036840600949330

Roed, K. (1996). Unemployment Hysteresis-Macro Evidence from 16 OECD Countries. Empirical Economics, 21, 589-600. http://dx.doi.org/10.1007/BF01180703

Schmidt, P., \& Phillips, P.C.B. (1992). LM Tests for a Unit Root in the Presence of Deterministic Trends. Oxford Bulletin of Economics and Statistics, 54, 257-287. http://dx.doi.org/10.1111/j.1468-0084.1992.tb00002.x

Song, F., \& Wu, Y. (1998). Hysteresis in Unemployment: Evidence from OECD Countries. The Quarterly Review of Economics and Finance, 38(2), 181-192.

Tolvi, J. (2003). Unemployment persistence of differentlabour force groups in Finland. Applied Economics Letters, 10, 455-8. http://dx.doi.org/10.1080/1350485032000089886

Yılancı, V. (2009). Yapısal Kırılmalar Altında Türkiye için İşsizlik Histerisinin Sınanması. DoğuşÜniversitesiDergisi, 10(2), 324-335. 